\title{
HUBUNGAN PENGETAHUAN, SIKAP DAN MOTIVASI IBU DENGAN PERILAKU PENCEGAHAN KEJANG DEMAM BERULANG PADA BALITA USIA 1- 5 TAHUN DI RSUD RADEN MATTAHER JAMBI
}

\author{
Untung Tarunaji ${ }^{1}$, Fithriyani ${ }^{2}$ \\ Sekolah Tinggi Ilmu Kesehatan Baiturrahim Jambi \\ Email: fithri.yani25@gmail.com
}

\begin{abstract}
A febrile seizure is a seizure that occurs when an infant or child has a fever without central nervous system infection that occurs at temperatures over $38^{\circ}$ C. a febrile seizure is seizure type most often encountered in childhood. This study aimed to determine the correlation of knowledge, attitude and mother's motivation with behavior of febrile seizures prevention in toddlers' age 1-5 years in the child's room RSUD Raden Mattaher Jambi year 2017. This is a quantitative research by using cross sectional design, it used Accidental Sampling by using questionnaire instrument. This study analyzed as univariate and bivariate by using chi-square test with significant levels $95 \%(<0.05)$.The findings indicated that, 35 respondents as many as 19 (54.3\%) have low knowledge, less good attitude as many as 20 (57.1\%), less good motivation as many as 18 (51.4\%) and less good prevention behavior 18 (51.4\%). The result of chi-square test indicated that there is the correlation of knowledge, attitude and mother's motivation with behavior of febrile seizures prevention in toddlers age 1-5 years in the child's room RSUD Raden Mattaher Jambi year 2017 with p-value < 0.05 while the motivation, there is no correlation with behavior of febrile seizures prevention in toddlers age 1-5 years in the child's room RSUD Raden Mattaher Jambi year 2017 p-value > 0.05. It is expected to RSUD Raden Mattaher Jambi is not only providing treatment but also providing health education periodically to increase of knowledge, attitude and mother's motivation so the febrile seizures do not reoccur.
\end{abstract}

Key note : Knowledge, Attitude, Motivation, behavior of febrile seizures prevention.

\section{ABSTRAK}

Kejang demam adalah kejang yang terjadi pada saat bayi atau anak mengalai demam tanpa infeksi sisitem saraf pusat yang terjadi pada suhu lebih dari $38^{0} \mathrm{C}$. Kejang demam merupakan tipe kejang yang paling sering di jumpai pada masa kanak- kanak. Tujuan penelitian ini adalah untuk mengetahui hubungan antara penegetahuan, sikap dan motivasi ibu dengan perilaku Pencegahan Kejang Demam Berulang pada Balita Usia 1- 5 Tahun di ruang anak RSUD Raden Mattaher Jambi tahun 2017. Jenis penelitian ini merupakan kuantitatif dengan desain cros sectional. Teknik pengambilan sampel adalah accidental sampling. Populasi dalam penelitian ini adalah seluruh penderita kejang demam pada anak di ruang anak RSUD Raden Mattaher Jambi tahun 2016 yaitu berjumlah 125 orang, sampel dalam penelitian ini adalah 35 orang. Data kemudian di olah dengan analisa univariat dan bivariat dengan menggunakan uji chiSquare. Hasil analisa univariat didapatkan 19 responden $(54,3 \%)$ memiliki pengetahuan rendah, Sikap sebanyak $20(57,1 \%)$ responden kurang baik, motivasi kurang baik 18 responden $(51,4 \%)$ dan prilaku pencegahan kejang demam 18 responden $(51,4 \%)$ kurang baik. Hasil analisa bivariat ada hubungan pengetahuan dengan perilaku pencegahan kejang demam berulang p-value 0,000), ada hubungan sikap dengan perilaku pencegahan kejang demam berulang p-value 0,028 dan tidak ada hubungan motivasi dengan perilaku pencegahan kejang demam berulang pada balita usia1-5 tahun di ruang anak RSUD raden mattaher jambi tahun 2017engand $p$-value 0,400. Bagi Rumah Sakit Raden Mataher Jambi tidak hanya melaksanakan pengobatan akan tetapi juga melakukan pendidikan kesehatan kepada keluarga tentang pencegahan kejang demam berulang diruang rawat inap Anak.

Kata Kunci: Pengetahuan, Sikap,Motivasi, Perilaku pencegahan kejang demam berulang 


\section{PENDAHULUAN}

Kejang demam adalah kejang yang terjadi pada saat bayi atau anak mengalai demam tanpa infeksi sisitem saraf pusat yang terjadi pada suhu lebih dari $38^{0} \mathrm{C}$. Kejang demam jarang terjadi setelah anak usia 5 tahun, anak laki- laki sering menderita kejang demam dengan insiden sekitar dua kali lipat lebih sering dibandingkan anak perempuan (Yusuf, 2014)

Setiap anak memiliki ambang kejang yang berbeda- beda. Anak dengan ambnag kejang rendah, kejang dapat terjadi pada suhu $38^{0} \mathrm{C}$. Tetapi pada anak dengan yang ambang tinggi kejang baru akan terjadi pada suhu $40^{\circ} \mathrm{C}$ atau bahkan lebih. Kejang demam sering terjadi pada anak dengan ambnag kejang rendah (Yusuf, 2014)

Kejang demam menurut defenisi Internasional League Against Epilepsy (ILAE) adalah kejang yang terjadi pada anak- anak di atas usia satu bulan karena demam dan bukan karena penyakit infeksi sistem saraf pusat, tidak ada riwayat kejang pada saat neonatus atau riwayat kejang tanpa faktor penyebab. Defenisi lain menurut American Academy of Pediatrics menyatakan bahwa kejang demam adalah kejang pada anak sekitar 6 bulan sampai 6 tahun yang terjadi saat demam yang tidak terkait dengan kelainan intrakranial, gangguan metabolik, atau riwayat kejang tanpa demam (Lemmens, 2005 dalam Susilowati, 2016). Kejang demam atau fulebrile convultansion ialah kejang yang terjadi pada kenaikan suhu tubuh (suhu rektal di atas 38 derajat celcius) yang disebabkan oleh proses ekstrakranium. Kejang demam adalah kejang yang terjadi pada suhu badan tinggi. Suhu badan tinggi ini karena kelainan ekstrakranial (Lestari, 2016). Akibat dari kejang demam dapat merusak neurotransmiter yaitu lepasnya muatan listrik yang demikian besarnya sehingga dapat meluas ke seluruh sel ataupun ke membran sel yang menyebabkan kerusakan pada neuron, epilepsi, kelainan anatomis otak, mengalami kecacatan/ kelainan neurologis dan kemungkinan mengalami kematian (Putra HR dkk, 2011)
Kejang demam merupakan tipe kejang yang paling sering di jumpai pada masa kanakkanak. Kejang demam biasanya menyerang anak dibawah 5 tahun, dengan insiden puncak yang terjadi pada anak usia antara 14 dan 18 bulan. Kejang demam terjadi pada anak di bawah 6 bulan dan di atas 5 tahun. Kejang demam berkaitan dengan demam, biasanya terkait dengan virus. Kejang tersebut biasanya jinak, tetapi sangat menakutkan baik bagi anak maupun keluarga. Pada sebagian besar kasus prognosis sangat baik. Bagaimanapun, kejang demam dapat menjadi tanda bahaya infeksi yang menyebabkan kejang tersebut seperti meningitis atau sepsis (Williams \& Wilkins, 2015).

Angka kejadian kejang demam di Amerika Serikat dan di Eropa Barat pada tahun 2004 berkisar antara 3\%- 4\%. Angka kejadian di Asia pada tahun 2004 dari seluruh kejang, 20\% anak mengalami kejang demam kompleks (Karimzadeh dalam Yusuf, 2014). Berdasarkan hasil Survey Demografi Kesehaatan Indonesia (SDKI) tahun 2012, di Indonesia tahun 2010 kejang demam termasuk sebagai lima penyakit anak terpenting yaitu $20,3 \%$, meningkat pada tahun 2012 dengan kejadian kejang demam sebesar 25,7\% ( Marwan, 2014).

Kejang demam anak perlu diwaspadai, karena kejang yang lama lebih dari 15 menit dapat menyebabkan kecacatan otak bahkan kematian. Dalam 24 jam pertama walaupun belum bisa dipastikan terjadi kejang, bila anak mengalami demam hal yang yang terpenting dilakukan adalah menurunkan suhu tubuh (Candra, 2009 dalam Labir K, dkk, 2013).

Langkah awal yang yang dapat dilakukan dalam melakukan pertolongan pertama untuk mencegah terjadinya kejang pada anak demam adalah segera memberi obat penurun demam, kompres air biasa atau hangat yang diletakan di dahi, ketiak, dahi, ketiak, dan lipatan paha. Beri anak banyak minum dan makan makanan berkuah atau buah- buahan yang banyak mengandung air, bisa berupa jus, susu, teh dan minuman lainnya. Jangan selimuti anak dengan selimut yang tebal, itu dapat menghalangi penguapan. Ketika terjadi kejang 
yang tidak berhenti setelah 15 menit, sebaiknya anak segera di bawa ke fasilitas kesehatan (Candra, 2009 dalam Labir K, dkk, 2013). Disinilah peran perawat selain melaksanakan asuhan keperawatan, juga memberikan penyuluhan kepada keluarga agar keluarga agar dapat melakukannya secara mandiri di rumah (Ngastiyah, 2005 dalam Putra, HR dkk, 2011).

Orang tua atau pengasuh anak harus di beri cukup informasi dalam upaya mencegah dan menghadapi kejang demam. Tindakan awal penatalaksanaan serangan kejang demam pada anak sangat tergantung pada peran orang tua atau pengasuhnya, terutama ibu. Ibu merupakan bagian integral dari sistem kehidupan rumah tangga atau keluarga yang dengan kesabaran dan kasih sayangnya dibutuhkan untuk merawat anak secara terampil agar tumbuh dan berkembang dengan sehat dan optimal (Rahayu, 2015)

Serangan kejang demam ini sulit diidentifikasi kapan munculnya, maka orangtua atau pengasuh anak terutama ibunya, perlu diberikan pengetahuan tentang kejang demam dan tindakan awal penatalaksanaan kejang demam dirumah pada anak yang mengalami serangan kejang demam. Orangtua atau pengasuh yang memiliki pengetahuan yang cukup tentang penatalaksanaann kejang demam dapat menentukan tindakan yang terbaik bagi anaknya (Rahayu, 2015).

Tindakan penatalaksanaan kejang demam tentunya dipengaruhi oleh perilaku dari ibu dimana perilaku itu didasarkan oleh pengetahuan, sikap dan motivasi. Pengetahuan sebagai hasil dari tahu yang terjadi setelah seseorang melakukan pengindraan terhadap suatu objek tertentu. Pengetahuan tentang deteksi dini yang di miliki keluarga balita tentang kejang demam sangatlah diperlukan (Notoatmodjo, 2012). Apabila pengetahuan tentang pencegahan dan penanganan cukup baik akan berpengaruh pada sikap yang baik pula pada keluarga untuk melakukan pencegahan dan penanganan kejang demam di rumah. Bila seseorang mempunyai sikap terhadap suatu objek, itu menunjuk dan sikan pengetahuan orang tersebut terhadap objek sikap yang bersangkutan Setelah pengetahuan dan sikap keluarga menjadi lebih baik, diharapkan mereka akan bersikap kooperatif dalam melakukan perilaku

pencegahan dan penanganan kejang demam.Motivasi berkaitan dengan pengetahuan dan sikap seseorang, jika pengetahuan dan sikapnya baik maka ini akan berdampak pada motivasinya untuk meraih seseuatu (Notoatmodjo, 2012).

Berdasarkan hasil penelitian yang dilakukan Kusuma (2016) dengan judul penelitian hubungan antara pengetahuan dengan perilaku ibu tentang pencegahan kejang demam pada balita di posyandu Gondangsar Juwiring Klaten dengan metode kuantitatif descriptif corelationl dengan pendekatan cross sectional dengan jumlah sampel 33 ibu di dapatkan hasil bahwa ada hubungan antara pengetahuan dengan perilaku ibu tentang pencegahan kejang demam pada anak balita di posyandu Gondangsari juwiring Klaten dengan $\mathrm{p}=0,005$.

Sedangkan hasil penilitian yang dilakukan oleh Fauzia (2012) dengan judul penelitian pengetahuan, sikap dan perilaku ibu mengenai kejang demam pada anak di puskesmas Ciputat timur dengan jenis penelitian cross- sectional, penelitian ini dilakukan secara deskriptif- analitik dengan jumlah sampel 106 ibu didapatkan hasil bahwa terdapat hubungan bermakna antara pengetahuan responden dengan perilaku responden tentang kejang demam pada anak dengan $\mathrm{p}<0,05(\mathrm{p}=0,036)$

Berdasarkan survey awal yang peneliti lakukan pada tanggal 15 April 2017 di ruang anak RSUD Radden Mattaher Jambi dengan mewawancarai 5 orang ibu yang mempunyai anak yang di rawat di ruang anak yang mempunyai riwayat penyakit sekarang dengan demam yang beresiko kejang demam didapatkan hasil 4 di antaranya kurang mengetahui cara pencegahan kejang demam berdasarkan jawaban yang ibu jawab, dan hanya mampu menjawab 1 poin saja yaitu dengan menurunkan suhu tubuh anak dan ibu juga kurang memahami dan mengerti tentang akibat dari demam yang tinggi bisa beresiko terjadinya kejang demam dan ibu 
yang harus ibu lakukan apabila anak terjangkit kejang demam seperti jangan panik, regangkan pakaian yang ketat, menghitung waktu lama kejang, memberi penahan pada gigi anak dengan benda yang tidak keras, dan sebagainya.

Berdasarkan fenomena dan data- data di atas maka peneliti tertarik untuk melakukan penelitian tentang "Hubungan Pengetahuan, sikap dan motivasi ibu dengan perilaku Pencegahan Kejang Demam Berulang pada Balita Usia 1- 5 Tahun di ruang anak RSUD Raden Mattaher Jambi

\section{METODE PENELITIAN}

Jenis penelitian ini merupakan kuantitatif dengan desain cros sectional untuk melihat Hubungan Pengetahuan, sikap dan Motivasi ibu dengan perilaku Pencegahan Kejang Demam pada anak di ruang anak RSUD Raden Mattaher Jambi. Penelitian ini dilakukan pada Juni 2016. Teknik pengambilan sampel adalah accidental sampling. Populasi dalam penelitian ini adalah seluruh penderita kejang demam pada anak di ruang anak RSUD Raden Mattaher Jambi tahun 2016 yaitu berjumlah 125 orang, sampel dalam penelitian ini adalah 35 orang. Data kemudian di olah dengan analisa univariat dan bivariat dengan menggunakan uji chi-Square.

\section{HASIL DAN PEMBAHASAN}

\section{Pengetahuan}

Tabel 1 Distribusi Tingkat Pengetahuan Ibu tentang Pencegahan Kejang Demam Pada Balita di Ruang anak RSUD Raden Mattaher Jambi

\begin{tabular}{llll}
\hline No. & Pengetahuan & f & \multicolumn{1}{c}{} \\
\hline 1. & Rendah & 19 & $54,3 \%$ \\
2. & Tinggi & 16 & $45,7 \%$ \\
\hline & Jumlah & 35 & $100 \%$ \\
\hline
\end{tabular}

Berdasarkan tabel 1 dari 35 responden dapat diketahui bahwa ibu yang memiliki pengetahuan rendah sebanyak 19 responden
$(54,3 \%)$. Hal ini menunjukkan bahwa masih banyaknya pengetahuan ibu yang rendah tentang pencegahan kejang demam. Pada analisis kuisioner pengetahuan rendah misalnya pada pertanyaan apa pengertian demam, penyebab kejang demam sebaagian besar responden menjawab salah.

2. Sikap

Tabel 2 Distribusi Frekuensi Sikap Ibu tentang Pencegahan Kejang Demam Pada Balita di Ruang Anak RSUD Raden Mattaher Jambi

\begin{tabular}{lllc}
\hline No. & Sikap & f & \% \\
\hline 1. & Kurang & 20 & $57,1 \%$ \\
& Baik & & \\
2. & Baik & 15 & $42,9 \%$ \\
\hline Jumlah & 35 & $100 \%$ \\
\hline
\end{tabular}

Berdasarkan tabel 2 dari 35 responden dapat diketahui bahwa ibu yang memiliki sikap kurang baik mengenai pencegahan kejang demam yaitu sebanyak 20 responden ibu $(57,1 \%)$.Hal ini menunjukkan bahwa masih adanya sikap ibu yang kurang baik tentang pencegahan kejang demam. Pada analisi kuisioner sikap rendah salah satunya ditemukan pada pernyataan responden tidak setuju jika mengkompres dengan menggunakan air hangat

responden lebih memilih mengkompres menggunakan air dingin dan mengenal tandatanda kejang demam karena sebagian besar responden tidak mengetahui deteksi dini kejang demam.

\section{Motivasi}

Tabel 3 Distribusi Frekuensi Motivasi Ibu tentang Pencegahan Kejang Demam Pada Balita di Ruang Anak RSUD Raden Mattaher Jambi

\begin{tabular}{llrc}
\hline No. & Motivasi & f & \multicolumn{1}{c}{$\%$} \\
\hline 1. & Kurang & 18 & $51,4 \%$ \\
& Baik & & \\
2. & Baik & 17 & $48,6 \%$ \\
Jumlah & 35 & $100 \%$ \\
\hline
\end{tabular}


Berdasarkan table 3 dari 35 responden dapat diketahui bahwa ibu yang memiliki motivasi kurang baik mengenai pencegahan kejang demam yaitu sebanyak 18 responden ibu $(51,4$ $\%)$, Sehingga dapat disimpulkan masih banyak ibu yang memiliki motivasi kurang baik terhadap perilaku pencegahan kejang demam berulang. Motivasi kurang baik ditemukan pada analisis kuisioner pada pernyataan responden setuju jika tidak terdapat keluhan maka responden tidak akan melakukan deteksi pencegahan demam dan responden tidak setuju melakukan deteksi dini kejang demam dikarenakan responden kurang pengetahuan dan informasi kejang demam.

\section{Perilaku Pencegahan Kejang Demam}

Tabel 4 Distribusi Frekuensi Perilaku Ibu tentang Pencegahan Kejang Demam Pada Balita di Ruang Anak RSUD Raden Mattaher Jambi

\begin{tabular}{llcc} 
No. & Perilaku & f & \% \\
\hline 1. & Kurang baik & 18 & $51,4 \%$ \\
2. & Baik & 17 & $48,6 \%$ \\
\hline Jumlah & 35 & $100 \%$ \\
\hline
\end{tabular}

Berdasarkan tabel 4.4 dari 35 responden dapat diketahui bahwa ibu yang memiliki perilaku kurang baik mengenai pencegahan kejang demam yaitu sebanyak 18 responden ibu $(51,4 \%)$.Hal ini menunjukkan bahwa masih adanya perilaku ibu yang kurang baik tentang pencegahan kejang demam. Perilaku kurang baik ditemukan pada analisi kuisioner pada pernyataan responden ibu tidak mengkompres anak dengan menggunakan air hangat dan responden ibu tidak mencari tau lebih lanjut tentang informasi kejang demam karena responden menganggap kejang demam pada anak itu adalah hal biasa.

5. Hubungan pengetahuan dengan perilaku pencegahan kejang demam pada balita usia 1-5 tahun di Ruang Anak RSUD Raden Mattaher Jambi.

Tabel. 5 Hubungan pengetahuan dengan perilaku pencegahan kejang demam pada balita usia 1-5 tahun di Ruang Anak RSUD Raden Mattaher Jambi

\begin{tabular}{|c|c|c|c|c|c|c|c|}
\hline \multirow{3}{*}{$\begin{array}{l}\text { Pengeta } \\
\text { huan }\end{array}$} & \multicolumn{4}{|c|}{$\begin{array}{c}\text { Perilaku Pencegahan } \\
\text { kejang demam }\end{array}$} & \multicolumn{3}{|c|}{ Total } \\
\hline & & $\begin{array}{l}\text { urang } \\
\text { Baik }\end{array}$ & & baik & & & $\mathrm{p}$-value \\
\hline & $f$ & $\%$ & $\mathrm{f}$ & $\%$ & $\mathrm{f}$ & $\%$ & \\
\hline Rendah & 17 & 89,5 & 2 & 10,5 & 19 & 100 & م $0 \Omega$ \\
\hline Tinggi & 1 & 6,2 & 15 & 93,8 & 16 & 100 & 0,000 \\
\hline Jumlah & 18 & 51,4 & 17 & 48,6 & 35 & 100 & \\
\hline
\end{tabular}

Berdasarkan table 5 diketahui bahwa jumlah responden sebanyak 35 responden ibu dari 19 responden yang memiliki pengetahuan rendah dengan perilaku pencegahan kejang demam $17(89,5 \%)$ responden ibu kurang baik dan dari 16 responden ibu yang memiliki pengetahuan tinggi dengan perilaku pencegahan kejang demam $1(6,2 \%)$ kurang baik.

Berdasarkan uji statistic didapatkan nilai p-value $0,000(<0,05)$ maka dapat di simpulkan ada hubungan yang signifikan / bermakna antara pengetahuan dengan Perilaku Pencegahan Kejang. Demam Berulang pada balita usia 1-5 tahun di ruang anak RSUD Raden Mataher Jambi Tahun 2017. Pengetahuan adalah tahap perkembangan, latar belakang pendidikan kesehatan dan pengalaman masa lalu. Kemampuan kognitif seseorang dibentuk dari cara berpikir seseorang dan selalu berhubungan dengan tahap perkembangan individu.

Hasil penelitian ini sejalan dengan hasil penelitian yang dilakukan Kusuma (2016) dengan judul penelitian hubungan antara pengetahuan dengan perilaku ibu tentang pencegahan kejang demam pada balita di posyandu Gondangsar Juwiring Klaten dengan metode kuantitatif descriptif corelationl dengan pendekatan cross sectional dengan jumlah sampel 33 ibu di dapatkan hasil bahwa ada hubungan antara pengetahuan dengan perilaku ibu tentang pencegahan kejang demam pada anak balita di posyandu Gondangsari juwiring Klaten dengan $\mathrm{p}=0,005$.

Berdasarkan hasil penilitian yang dilakukan oleh Fauzia (2012) dengan judul penelitian pengetahuan, sikap dan perilaku ibu mengenai kejang demam pada anak di 
puskesmas Ciputat timur dengan jenis penelitian cross- sectional, penelitian ini dilakukan secara deskriptif- analitik dengan jumlah sampel 106 ibu didapatkan hasil bahwa terdapat hubungan bermakna antara pengetahuan responden dengan perilaku responden tentang kejang demam pada anak dengan $\mathrm{p}<0,05(\mathrm{p}=0,036)$.

6. Hubungan sikap dengan perilaku pencegahan kejang demam pada balita usia 1-5 tahun di Ruang Anak RSUD Raden Mattaher Jambi

Table .6 Hubungan sikap dengan perilaku pencegahan kejang demam pada balita usia 1-5 tahun di Ruang Anak RSUD Raden Mattaher Jambi

\begin{tabular}{|c|c|c|c|c|c|c|c|c|}
\hline \multirow{3}{*}{ No } & \multirow{3}{*}{ Sikap } & \multicolumn{4}{|c|}{$\begin{array}{c}\text { Perilaku pencegahan } \\
\text { kejang demam }\end{array}$} & \multicolumn{2}{|c|}{$\begin{array}{r}\text { Tot } \\
\text { al } \\
\end{array}$} & \multirow{2}{*}{$\begin{array}{c}p- \\
\text { Valu } \\
e \\
\end{array}$} \\
\hline & & \multicolumn{2}{|c|}{$\begin{array}{l}\text { Kurang } \\
\text { baik }\end{array}$} & \multicolumn{2}{|c|}{ Baik } & & & \\
\hline & & $\mathbf{f}$ & $\%$ & f & $\%$ & f & $\%$ & \\
\hline 1. & $\begin{array}{l}\text { Kurang } \\
\text { baik }\end{array}$ & 14 & 70,0 & 6 & 30,0 & $\begin{array}{l}2 \\
0\end{array}$ & $\begin{array}{c}10 \\
0\end{array}$ & \\
\hline 2. & Baik & 4 & 26,7 & 11 & 73,3 & $\begin{array}{l}1 \\
5\end{array}$ & $\begin{array}{r}10 \\
0\end{array}$ & 0,028 \\
\hline Jum & & 18 & 51,4 & 17 & 48,6 & $\begin{array}{l}3 \\
5\end{array}$ & $\begin{array}{r}10 \\
0\end{array}$ & \\
\hline
\end{tabular}

Berdasarkan table 6 dapat dilihat dari 20 responden dengan sikap kurang baik $14(70,0 \%)$ responden dengan perilaku pencegahan kejang demam sedangkan dari 15 responden sikap baik sebanyak $4(26,7 \%)$ responden dengan perilaku pencegahan kejang demam.

Berdasarkan uji statistic didapatkan nilai p-value $0,028(<0,05)$ maka dapat di simpulkan ada hubungan yang signifikan / bermakna antara sikap dengan Perilaku Pencegahan Kejang Demam Berulang pada balita usia 1-5 tahun di ruang anak RSUD Raden Mataher Jambi Tahun 2017. Hasil penilitian sejalan dengan hasil penelitian yang dilakukan oleh Fauzia (2012) dengan judul penelitian pengetahuan, sikap dan perilaku ibu mengenai kejang demam pada anak di puskesmas Ciputat timur dengan jenis penelitian cross- sectional, penelitian ini dilakukan secara deskriptif- analitik dengan jumlah sampel 106 ibu didapatkan hasil bahwa terdapat hubungan bermakna antara sikap responden dengan perilaku responden tentang kejang demam pada anak dengan $\mathrm{p}<0,05(\mathrm{p}=$ $0,002)$.

\section{Hubungan motivasi ibu dengan perilaku pencegahan kejang demam pada balita usia 1-5 tahun di Ruang Anak RSUD Raden Mattaher Jambi}

Tabel 7 Hubungan motivasi ibu dengan perilaku pencegahan kejang demam pada balita usia 1-5 tahun di Ruang Anak RSUD Raden Mattaher Jambi

\begin{tabular}{|c|c|c|c|c|c|c|c|c|}
\hline \multirow[t]{3}{*}{ No } & \multirow[t]{3}{*}{ Motivasi } & \multicolumn{4}{|c|}{$\begin{array}{l}\text { Perilaku pencegahan } \\
\text { kejang deman }\end{array}$} & \multicolumn{2}{|c|}{ Total } & \multirow[t]{2}{*}{$\begin{array}{c}p \text { - } \\
\text { Value }\end{array}$} \\
\hline & & \multicolumn{2}{|c|}{$\begin{array}{c}\text { Kurang } \\
\text { baik }\end{array}$} & \multicolumn{2}{|c|}{ Baik } & & & \\
\hline & & $\mathbf{f}$ & $\%$ & $f$ & $\%$ & f & $\%$ & \\
\hline 1. & $\begin{array}{l}\text { Kurang } \\
\text { baik }\end{array}$ & 11 & 61,1 & 7 & 38,9 & 18 & 100 & 0,400 \\
\hline 2. & Baik & 7 & 41,2 & 10 & 58,8 & 17 & 100 & \\
\hline & Jumlah & 18 & 51,4 & 17 & 48,6 & 35 & 100 & \\
\hline
\end{tabular}

Berdasarkan table 7 dapat dilihat dari 18 responden dengan motivasi kurang baik 11 $(61,1 \%)$ responden dengan perilaku pencegahan kejang demam sedangkan dari 17 responden dengan motivasi baik $7(41,2 \%)$ responden dengan perilaku pencegahan kejang demam.

Hasil statistic didapatkan nilai $\mathrm{p}$-value 0,400 ( $>>0,05)$ maka dapat disimpulkan tidak ada hubungan yang signifikan antara motivasi dengan perilaku pencegahan kejang demam. Berdasarkan hasil analisis kuisioner maka dapat disimpulkan bahwa sebagian besar responden rata-rata sudah memiliki motivasi baik terhadap perilaku pencegahan kejang demam berulang. Namun demikian pada kuisioner masih ditemukan responden dengan motivasi yang kurang baik. Pada hasil analisis kuisioner ditemukan sebanyak (60\%) menyatakan tidak setuju jika akan melakukan deteksi dini kejang demam pada anak saya 
atas kemauan sendiri dikarenakan kurang pengetahuan dari responden mengenai tandatanda kejang demam, sebanyak (45\%) menyatakan setuju karena tidak terdapat keluhan maka saya tidak akan melakukan pencegahan kejang demam karena responden menganggap demam yang terjadi itu adalah demam biasa, sebanyak (55\%) menyatakan tidak setuju saya akan selalu mencari informasi tentang kejang demam dikarenakan keterbatasan informasi dan akses informasi.

\section{SIMPULAN}

Hasil analisa univariat didapatkan bahwa dari 35 responden sebanyak 19 responden $(54,3 \%)$ ibu memiliki pengetahuan rendah, Sikap tentang pencegahan kejang demam sebanyak $20(57,1 \%)$ responden kurang baik, motivasi responden tentang pencegahan kejang demam kurang baik yaitu sebanyak 18 responden $(51,4 \%)$ dan prilaku pencegahan kejang demam sebanyak 18 responden $(51,4 \%)$ dengan perilaku kurang baik.

Hasil analisa bivariat didapatkan Ada hubungan pengetahuan dengan perilaku pencegahan kejang demam berulang pada balita usia1-5 tahun di ruang anak RSUD raden mattaher jambi tahun 2017 dengan p-value 0,000 $(\mathrm{P}<0,05)$. Ada hubungan sikap dengan perilaku pencegahan kejang demam berulang pada balita usia 1-5 tahun di ruang anak RSUD raden mattaher jambi tahun 2017 dengan p-value 0,028 $(\mathrm{P}<0,05)$. Tidak ada hubungan motivasi dengan perilaku pencegahan kejang demam berulang pada balita usia1-5 tahun di ruang anak RSUD raden mattaher jambi tahun 2017engand $p$-value $0,400(P>0,05)$.

\section{SARAN}

Bagi Rumah Sakit Raden Mataher Jambi tidak hanya melaksanakan pengobatan akan tetapi juga melakukan pendidikan kesehatan kepada keluarga tentang pencegahan kejang demam berulang diruang rawat inap Anak.

\section{DAFTAR PUSTAKA}

1. Kusuma (2016). Hubungan antara pengetahuan dengan perilaku ibu tentang pencegahan kejang demam pada balita di Posyandu Gondangsari Juwiring Klaten.Jurnal Volno 2 Maret 2016.

2. Labir,Kdkk (2013).Pertolongan Pertama dengan kejadian kejang demam pada anak.

3. Lestari, $T$ (2016). Asuhan keperawatan Anak.Nuha Medika . Yogyakarta.

4. Marwan,K (2014).Hubungan antara pengetauan orang tua tentang penanganan demam dengan kejadian kejang demam berulang di Posyandu Mawar Melati Cimahi JurnalVol 3 no 1Agustus 2014 .

5. Notoadmojo,S.(2010) Ilmu Perilaku Kesehatan . Pt Rineka Citra.Jakarta

6. Notoadmojo, S.(2012).Promosi Kesehatan Perilaku kesehatan. PT.Rineka Citra.Jakarta.

7. Putra, H.R(2011). Hubungan penegetahuan perawat tentang kejang demam dengan penanganan Kejang Demam Pada Anak di IGD anak ruang perawatan intensif Irna $E$ RSUP Prof.Dr.R.D Kondou Manado.Jurnal vol no lmaret 2011.

8. Rahayu, S. (2015). Model Pendidikan Kesehatan dalam meningkatkan pengelolaan kejang demam pada ibu balita diPosyandu Balita. Jurnal Terpadu Ilmu Kesehatan.Vol 4 No 1 Mei 2015.

9. Susilowati (2014).kesehatan dan praktik manajemen demam pada orang tua dengan anakkejang demam di ruang seruni RSUD Muntilan kabupaten Magelang. Jurnal vo 1 no2 Mei 2014.

10. Williams dan wilkins .( 2015). Buku ajar keperawatan pediatric 2 edisi 2.Buku Kedokteran .EGC. Jakarta

11. Yusuf, M.(2014). Pengaruh pendidikan kesehatan tentang penanganan kejang demam menggunakan audio visual terhadap tingkat pengetahuan dan sikap ibu dengan anak riwayat kejang demam. Jurnal vol 1 no 2 September 2014. 